\title{
Follicular Stem Cells in Androgenetic Alopecia
}

Hend Gamil, Magda Assaf, Manal Elsayed, Khaled Gharib*, Ayman Yosef, Mohamed Khater, Mohamed Nasr and Mohamed Soliman Department of Dermatology and Pathology, Faculty of Medicine, Zagazig University, Egypt

\begin{abstract}
Although the pathogenesis of androgenetic alopecia (AGA) is poorly understood, recent studies suggest that compromising the integrity of the follicular bulge area and or sebaceous gland may play a role. This study was designed to evaluate the role of follicular bulge stem cells in AGA. Twenty patients with AGA (17 males and 3 females) with a mean age of $24.05 \pm 1.6$ were the subjects of this study. A $4 \mathrm{~mm}$ punch biopsy specimen was obtained from both occipital skin and frontal affected area of scalp of each patient and embedded in paraffin. Tissue sections were immunostained using the Cytokeratin 15(CK 15) Ab-1 mouse monoclonal antibody. Cytokeratin 15 immunoreactivity was observed both in the frontal and occipital skin biopsies in the follicular bulge region and outer root sheath in all 20 AGA patients $(100 \%)$. This study suggests that follicular stem cells in the bulge region are not the target in AGA. Further studies using other stem cell markers are recommended to clarify the role of follicular stem cells in AGA pathogenesis.
\end{abstract}

Keywords: Androgenetic alopecia; Hair follicle stem cells; Bulge area; CK15

\section{Introduction}

Androgenetic alopecia, also referred to as male pattern hair loss or common baldness, is a slowly progressive form of alopecia which begins after the onset of puberty. It is characterized by progressive, patterned hair loss from the scalp, and occurs in both men and women [1]. It is assumed that the genetically predisposed hair follicles are the target for androgen-stimulated hair follicle miniaturization, leading to gradual replacement of large, pigmented hairs (terminal hairs) by barely visible, depigmented vellus hairs in affected areas [2].

Stem cells responsible for hair follicle cycling reside in the hair follicle bulge of both human and mouse skin. Bulge cells generate all the epithelium lineages within the follicle and their selective destruction leads to loss of the hair follicle. Also bulge cells give rise to progenitor population called secondary germ cells, which reside adjacent to the bulge during telogen and produce the new hair shaft at anagen onset [3].

In recent years, there have been few studies investigating the role of hair follicle stem cells in the pathogenesis of nonscarring alopecia including AGA [4]. Whether these findings will lead to a new area of explanation of the cause of AGA is still unknown. Global gene expression studies of isolated bulge cells from humans indicate preferential expression of the intermediate filament protein Keratin 15 (KRT15) and the cell surface marker CD200. Other markers of stem cells are Ki 67, CK19, P63 and CD34. In humans, CD34 expression is confined to cells immediately below the bulge in the outer root sheath of the anagen hair follicle. Thus, the use of these markers allows for assessment of stem and progenitor cell populations in human scalp [5].

\section{Patients and Methods}

Twenty patients with AGA presenting to the Dermatology Department of Zagazig University Hospitals during the period from January 2011 to December 2012 were the subjects of this study. They were 17 males and 3 females with their ages ranging from 20 to 29 years with a mean of $24.05 \pm 1.6$. The diagnosis of AGA was clinically established by the characteristic distribution of frontal and vertex hair in males and the Christmas tree pattern of diffuse hair loss at middle hairline in females.
All patients were subjected to thorough history taking with special reference to inclusion criteria: name, age (from 20 to 29 years old), sex, marital status, address, telephone number and occupation. History of present illness included the onset, course, duration and previous treatment as well as family history of thinning and visual confirmation of a receding frontal hairline, and the presence of thin and short hairs in the frontal area and vertex. Exclusion criteria: Diagnosis of androgenetic alopecia is relatively easy, but it is important to exclude chronic diffuse type alopecia areata, idiopathic chronic telogen effluvium, diffuse alopecia associated with systemic diseases such as collagen diseases and chronic thyroiditis, and the effect of general conditions such as anemia, crash diets, wasting disease, drugs and hormone replacement therapy. The type of AGA was identified in male patients according to the Norwood -Hamilton classification, and in females according to Ludwig classification (Table 1).

\section{Immunohistochemistry}

A $4 \mathrm{~mm}$ punch biopsy specimen was obtained from both the occipital scalp skin as control and the frontal affected area of each patient. The specimens were then subjected to immunostaining using the Cytokeratin 15(CK 15) Ab-1 mouse monoclonal antibody [6].

The specimens were placed in $10 \%$ neutral buffered formalin and sent for paraffin embedding. Tissue sections ( $4 \mu \mathrm{m}$ thickness) were obtained from paraffin blocks and treated with CK15 Ab-1 mouse monoclonal antibody (LHK15; 1: 250; NeoMarkers, Fremont, CA, U.S.A.). Sectioned tissue was deparaffinized with xylene and rehydrated through descending strengths of alcohol. The specimens were put in an oven for 2 hours then treated with xylene for 2 minutes and with alcohol (70\%, 80\%, 90\%, and 100\%) each concentration for 2 minutes. Washing in distilled water was done for 2 minutes.

*Corresponding author: Khaled Gharib, Department of Dermatology and Pathology, Faculty of Medicine, Zagazig University, Egypt, Tel: 00201001658084 . E-mail:kh_gharib@hotmail.com

Received March 30, 2015; Accepted April 27, 2015; Published April 29, 2015

Citation: Gamil H, Assaf M, Elsayed M, Gharib K, Yosef A, et al. (2015) Follicular Stem Cells in Androgenetic AlopeciaJ Cytol Histol 6: 324. doi:10.4172/21577099.1000324

Copyright: @ 2015 Gamil H, et al. This is an open-access article distributed under the terms of the Creative Commons Attribution License, which permits unrestricted use, distribution, and reproduction in any medium, provided the original author and source are credited. 
Citation: Gamil H, Assaf M, Elsayed M, Gharib K, Yosef A, et al. (2015) Follicular Stem Cells in Androgenetic AlopeciaJ Cytol Histol 6: 324. doi:10.4172/2157-7099.1000324

\begin{tabular}{|c|c|c|}
\hline & Number & Percentage \\
\hline $\begin{array}{l}\text { Age ( years): } \\
\text { Mean + SD } \\
\text { ( Range ) }\end{array}$ & \multicolumn{2}{|c|}{$\begin{array}{c}24.05 \pm 1.6 . \\
(20 \text { to } 29)\end{array}$} \\
\hline $\begin{array}{l}\text { Sex: } \\
\text { Male } \\
\text { Female }\end{array}$ & $\begin{array}{c}17 \\
3\end{array}$ & $\begin{array}{l}85 \% \\
15 \%\end{array}$ \\
\hline $\begin{array}{l}\text { Family history: } \\
\text { Negative } \\
\text { Positive }\end{array}$ & $\begin{array}{c}2 \\
18\end{array}$ & $\begin{array}{l}10 \% \\
90 \%\end{array}$ \\
\hline $\begin{array}{l}\text { AGA type: } \\
\text { Norwood classification (17) } \\
\text { Type IV : } \\
\text { Type V : } \\
\text { Type Va : } \\
\text { Type VI : }\end{array}$ & $\begin{array}{l}2 \\
3 \\
4 \\
8\end{array}$ & $\begin{array}{l}10 \% \\
15 \% \\
20 \% \\
40 \%\end{array}$ \\
\hline $\begin{array}{l}\text { Ludwig classification (3) } \\
\text { Type II : } \\
\text { Type III : }\end{array}$ & $\begin{array}{l}1 \\
2\end{array}$ & $\begin{array}{l}5 \% \\
10 \%\end{array}$ \\
\hline $\begin{array}{l}\text { Duration : } \\
\text { Mean + SD } \\
\text { Range }\end{array}$ & \multicolumn{2}{|c|}{$\begin{array}{c}3.175 \pm 2.014 . \\
\quad(1-6 Y)\end{array}$} \\
\hline $\begin{array}{l}\text { Previous therapy: } \\
\text { Minoxidil } \\
\text { Finastride } \\
\text { Dutasteride } \\
\text { Mesotherapy } \\
\text { Others treatments }\end{array}$ & $\begin{array}{c}17 \\
-- \\
--- \\
3 \\
---\end{array}$ & $\begin{array}{c}85 \% \\
--- \\
--- \\
15 \% \\
---\end{array}$ \\
\hline
\end{tabular}

Table 1: Demographic data and clinical characteristics of studied patients.

The retrieval of the CK15 antigen was done by autoclaving the slides with $10 \mathrm{mM}$ citrate buffer at $21^{\circ} \mathrm{C}$ for 30 minutes in pressure cooker at PH 6. Cooling at room temperature was done for 20 minutes then washing in PBS. Endogenous peroxidase activity was blocked by incubating slides in 2\% hydrogen peroxide for 10 minutes followed by washing in PBS. Blocking was done for non-specific protein binding with normal goat serum and bovine serum albumin followed by washing in PBS. Subsequently the slides were stained using a labeled biotin streptavidin method.

The slides were incubated for one hour at $21^{\circ} \mathrm{C}$ in a humidified chamber with a primary antibody. Incubation with rabbit polyclonal antibody against CK15 Ab-1 mouse monoclonal antibody was done followed by washing in PBS. Incubation with biotinylated link antibody was performed for $30 \mathrm{~min}$ at room temperature followed by washing in PBS. The slides were then incubated with peroxidase-labeled streptavidin for $15 \mathrm{~min}$ at room temperature then washed. Diaminobenzidine (DAB) was applied as chromogen followed by counter staining with hematoxylin for 30 seconds. Washing was done with distilled water for 2 minutes and alcohol $(70 \%, 80 \%, 90 \%$, and $100 \%)$, each concentration for 2 minutes. Clearing and mounting with Xylene was done and the slides were covered with cover slip and examined. Positive staining was noted by ascertaining expression of CK15 in the cytoplasm and any nuclear staining considered background artefact [7].

\section{Statistical analysis}

The data were tabulated and statistically analyzed using the SPSS for Windows 10.0 statistical package program. Paired data of qualitative variable were estimated by McNemars chi-square test $\left(\mathrm{X}^{2}\right)$ and Wilcoxon signed rank test. Quantitative data and numerical variables were expressed as mean () and standard deviation (SD). Probability of $\mathrm{P}$-value $<0.05$ was considered to be statistically significant.

\section{Results}

Twenty patients with AGA (17 males and 3 females), in male AGA patients according to the Norwood -Hamilton classification were: 8 patients with type VII, 4 patients with type VI, one patient with type V, 3 patients with type Va and one patient with type IV and in female AGA patients according to Ludwig classification were: 2 patients with type III and one patient with type II (Table 1).

The immunohistochemical staining showed positive expression of CK15 in skin biopsies from both frontal and occipital scalp skin in all 20 AGA patients (100\%) (Figures 1 and 2) (Table 2). CK15 was expressed in the bulge region and outermost cell layer of the external root sheath, at the level of the isthmus. Specifically, the CK15 immunostaining extended from the entrance of the sebaceous gland duct down to the insertion site of the arrector pili muscle (Figures 3 and 4). This CK15 staining was maintained throughout the different phases of the hair follicle cycle (Table 3).

\section{Evaluation of staining results}

- CK15 positive staining was noted by ascertaining CK15 expression in cytoplasm. Any nuclear stain was considered background artifact [7].

$>$ Positive slides showed brown colored precipitate. The percentage of positive cells was calculated in 100 cells / $4 \mathrm{HPF}$.

$>$ Criteria for grading stained sections were:

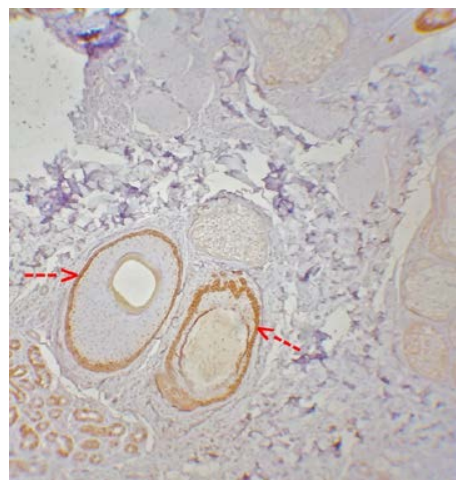

Figure 1: CK15 positivity within occipital hair follicle, cross section (200X)

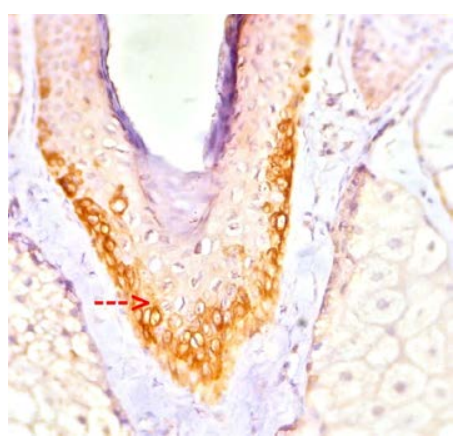

Figure 2: CK 15 positivity within the bulge region of frontal hair follicle of the same patient, longitudinal section (400X).

\begin{tabular}{|l|c|c|c|c|}
\hline \multirow{2}{*}{ CK15 } & \multicolumn{2}{|c|}{ Frontal } & \multicolumn{2}{c|}{ Occipital } \\
\cline { 2 - 5 } & No. & $\%$ & No. & $\%$ \\
\hline Positive & 20 & $100 \%$ & 20 & $100 \%$ \\
\hline Negative & 0 & 0 & 0 & 0 \\
\hline
\end{tabular}

Table 2: Comparison of CK15 expression in frontal versus occipital skin. 
Citation: Gamil H, Assaf M, Elsayed M, Gharib K, Yosef A, et al. (2015) Follicular Stem Cells in Androgenetic AlopeciaJ Cytol Histol 6: 324. doi:10.4172/2157-7099.1000324

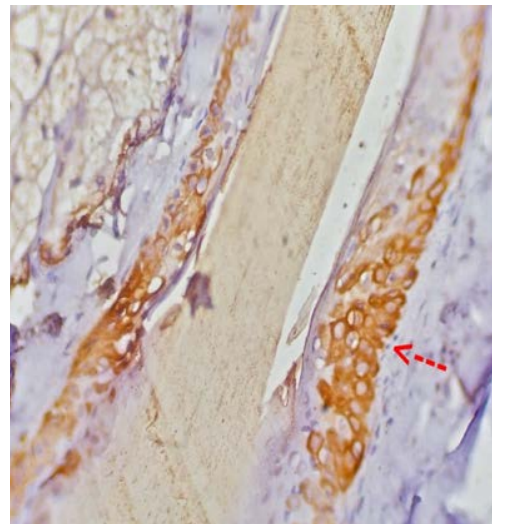

Figure 3: CK 15 positivity within the bulge region and outermost cell laye of the external root sheath, at the level of the isthmus of frontal hair follicle, longitudinal section $(400 \mathrm{X})$

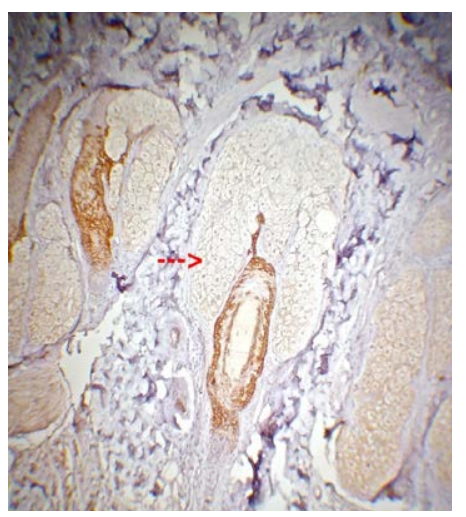

Figure 4: CK15 positivity within frontal hair follicle at level sebaceous glands, cross section (200X)

\begin{tabular}{|l|c|c|c|c|}
\hline \multirow{2}{*}{ Staining degree } & \multicolumn{2}{|c|}{ Frontal } & \multicolumn{2}{c|}{ Occipital } \\
\cline { 2 - 5 } & No. & $\%$ & No. & $\%$ \\
\hline -ve & 0 & 0 & 0 & 0 \\
\hline+ ve & 20 & $100 \%$ & 20 & $100 \%$ \\
\hline$++v e$ & 0 & 0 & 0 & 0 \\
\hline +++ve & 0 & 0 & 0 & 0 \\
\hline
\end{tabular}

-ve : negative, +ve : mild positivity, ++ve : moderate positivity and +++ve : strong positivity.

Table 3: Staining degree of CK15 in frontal versus occipital skin.

- $\quad$ Negative (-): if $<5 \%$ positive cells.

- Weakly positive (+): if $5 \%-25 \%$ positive cells.

- Moderately positive $(++)$ : if $>25-50 \%$ positive cells.

- Strongly positive $(+++)$ : if $>50 \%$ positive cells.

\section{Discussion}

The function of the bulge region of the hair follicle remained unknown until the recognition of the monoclonal antibody to CK15 that specifically targeted keratinocytes in this region. Using this antibody it was apparent that hair follicle bulge cells possess characteristics of SCs such as multipotency, high proliferative potential and quiescence [8]. Human bulge cells have been reported to express CK15 selectively throughout all stages of the hair cycle in different types of follicles [9].
More recently it has been shown that CK15+ cells are lost in some scarring alopecia, implying involvement of the bulge region in scarring alopecia [7]. AGA represents the most common type of nonscarring alopecia and permanent alopecia may occur in long-standing cases. This irreversibility of the ability to grow hair again may give rise to the possibility of stem cell involvement in this type of alopecia [10].

In this study, CK15 immunoreactivity was detected both in the occipital and the frontal affected skin in all 20 patients (100\%). The CK15 expression was noted in the follicular bulge region and peripheral layer of the outer root sheath. These results show that the stem cells in bulge region are preserved in AGA. Similarly Hoang et al. [7] also reported expression of CK15 in the follicular bulge region in 27 of 27 AGA patients (100\%). In addition CK15 staining was noted in the peripheral layer of the outer root sheath above the attachment of the pilar muscle in $100 \%$ of cases.

The location of human hair follicle SCs has long been the subject of debate. While Lyle et al. [11] reported that SCs are believed to be confined to the bulge region, Commo et al. [12] have suggested that distinct populations of SCs may exist. Similarly, Hoang et al. [7] suggested that the bulge region is not the only reservoir of SCs in the follicle and that distinct populations of SCs appear to exist in different compartments. This may suggest that the target in AGA may be in other areas of follicle.

Although AGA is considered a noninflammatory form of hair loss, sometimes a superficial, perifollicular, inflammatory infiltrate 'microinflammation' is noted and eventually fibrosis and the bulge may actually be directly targeted by inflammation as well. Over time, this damage could contribute to the irreversible nature of AGA. On the other hand, Garza et al. [5] suggested that AGA is not characterized by loss of follicular stem cells but by a defect in the conversion of these stem cells into active progenitor cells leading to hair follicle miniaturization.

In conclusion, the pathogenesis of AGA is not fully understood; this study suggests that CK15 found in follicular stem cells in the bulge region, in frontal and occipital areas which means that follicular stem cells is still present in AGA. Further studies using other stem cell markers are recommended to clarify the role of stem cells in AGA.

\section{References}

1. Tsuboi R, Itami S, Inui S, Ueki R, Katsuoka K, et al. (2012) Guidelines for the management of androgenetic alopecia (2010). J Dermatol 39: 113-120.

2. Dahl MV (2012) Stem cells and the skin. J Cosmet Dermatol 11: 297-306.

3. Zhang YV, Cheong J, Ciapurin N, McDermitt DJ, Tumbar T (2009) Distinct self-renewal and differentiation phases in the niche of infrequently dividing hair follicle stem cells. Cell Stem Cell 5: 267-278.

4. Amoretti A, Laynder $H$, Bergfeld $W$ (2012) Androgenic alopecia and risk prostatic cancer: A systematic review and meta-analysis. J Am Acad Dermatol 66: 35-40.

5. Garza LA, Yang CC, Zhao T, Blatt HB, Lee M, et al. (2011) Bald scalp in men with androgenetic alopecia retains hair follicle stem cells but lacks CD200-rich and CD34-positive hair follicle progenitor cells. J Clin Invest 121: 613-622.

6. Al-Refu K (2012) Stem cells and alopecia: a review of pathogenesis. $\mathrm{Br} J$ Dermatol 167: 479-484.

7. Hoang MP, Keady M, Mahalingam M (2009) Stem cell markers (cytokeratin 15 , CD34 and nestin) in primary scarring and nonscarring alopecia. Br J Dermatol 160: 609-615.

8. Miteva M, Tosti A (2012) Hair and scalp dermatoscopy. J Am Acad Dermatol 67: 1040-1048.

9. Randall VA (2010) Molecular Basis of Androgenetic Alopecia. In: Ralph MT Desmond T, Aging Hair. Springer-Verlag Berlin Heidelberg. 
Citation: Gamil H, Assaf M, Elsayed M, Gharib K, Yosef A, et al. (2015) Follicular Stem Cells in Androgenetic AlopeciaJ Cytol Histol 6: 324. doi:10.4172/2157-7099.1000324

Page 4 of 4

10. Zhao L, Hantash BM (2011) Male androgenetic alopecia is due to hair follicle stem cell inactivation. Expert Rev Dermatol 6: 9-17

11. Lyle S, Christofidou-Solomidou M, Liu Y, Elder DE, Albelda S, et al. (1999) Human hair follicle bulge cells are biochemically distinct and possess an epithelial stem cell phenotype. J Investig Dermatol Symp Proc 4: 296-301.

12. Commo S, Gaillard O, Bernard BA (2000) The human hair follicle contains two distinct K19 positive compartments in the outer root sheath: a unifying hypothesis for stem cell reservoir? Differentiation 66: 157-164. 